\title{
Analisis Beban Kerja Fisiologis sebagai Dasar Penentuan Waktu Istirahat untuk Mengurangi Kelelahan Kerja
}

\author{
Wahyu Hidayat $^{1}$, Trismi Ristyowati ${ }^{1}$, Gunawan Madyono Putro ${ }^{1}$ \\ Program Studi Teknik Industri, Fakultas Teknik Industri \\ Universitas Pembangunan Nasional "Veteran" Yogyakarta \\ email : bagus2007@ymail.com \\ doi: https://doi.org/10.31315/opsi.v13i1.3469
}

Received: $11^{\text {th }}$ June 2020; Revised: $30^{\text {th }}$ June 2020; Accepted: $30^{\text {th }}$ June 2020;

Available online: $30^{\text {th }}$ June 2020; Published regularly: June 2020

\begin{abstract}
510 minutes of work time a day with a break of 30 minutes is felt by employees of PT. Yogya Indo Global is too heavy. This company, which is engaged in wood processing, has 4 work stations, namely the Plenner process station, the Jointer process, Telthing and cutting parts. To reduce the physical workload in this study will be determined the length of rest time using the Indirect Assessment Method with categories of physical (physiological) workload, pulse (beats / minutes), classification\% CVL (Cardiovasculair Load), calculating energy consumption, and calculate the need for rest. The study was conducted at rest at 09.30 and at 15.00 WIB. Pulse measurements are carried out using the 10 Pulse Method which then affects the amount of energy consumption. Based on the research results, it is known that at the Plenner machine work station, the Jointer and Telthing machines are in the classification of\% CVL, the workload is due to the level of 30\% -60\%. Based on the results of the calculations, the work station for the Plenner, Jointer, Telthing and cutting process needs to be added by each time by 10 minutes, 5 minutes, 13 minutes and 10 minutes at 09.30 and the addition of 28 minutes, 25 minutes, 35 minutes and 15 at 3:00 p.m..
\end{abstract}

Keywords: Break Time; Physiological Workload; \% CVL; 10 Pulse Method

\begin{abstract}
ABSTRAK
Waktu kerja 510 menit sehari dengan waktu istirahat 30 menit di dirasakan oleh karyawan PT. Yogya Indo Global terlalu berat. Perusahaan yang bergerak dalam bidang pengolahan kayu ini mempunyai 4 stasiun kerja yaitu stasiun proses Plenner, proses Jointer, Telthing dan potong belah. Untuk mengurangi beban kerja fisik tersebut pada penelitian ini akan dilakukan penentuan lama waktu istirahat menggunakan Metode Penilaian Tidak Langsung dengan kategori beban kerja fisik (fisiologis), Denyut Nadi (denyut/menit), klasifikasi \%CVL (Cardiovasculair Load), menghitung konsumsi energi, dan menghitung kebutuhan waktu istirahat. Penelitian dilakukan pada waktu istirahat Pukul 09.30 dan Pukul 15.00 WIB. Pengukuran denyut Nadi dilakukan menggunakan Metode 10 Denyut yang kemudian berpengaruh pada jumlah konsumsi energi. Berdasarkan hasil penelitian diketahui bahwa pada stasiun kerja mesin Plenner, mesin Jointer dan dan Telthing berada dalam klasifikasi \% CVL beban kerja sedang hal ini dikarenakan berada pada level 30\%-60\%. Berdasarkan hasil dari perhitungan maka pada stasiun kerja proses Plenner, Jointer, Telthing dan potong belah perlu dilakukan penambahan waktu masing-masing sebesar 10 menit, 5 menit, 13 menit dan 10 menit pada pukul 09.30 dan penambahan 28 menit, 25 menit, 35 menit dan 15 pada pukul 15.00.
\end{abstract}

Kata Kunci: Waktu Istirahat; Beban Kerja Fisiologis; \%CVL; Konsumsi Energi

\section{PENDAHULUAN}

Faktor kerja fisik sangat menentukan akan jumlah produksi. selama proses kerja fisik karyawan akan mengeluarkan energy sehingga sehingga agar proses produksi tetap optyimal maka perlu dilakukan keseimbangan antara pengeluaran dan pemulihan energi. Adapun faktor yang berpengaruh terhadap pemulihan energy antara lain adalah waktu istirahat, periode istirahat, dan frekuensi istirahat. Adapun kelehan dapat dibedakan menjadi dua hal yaitu kelelahan fisiologis dan kelelahan psikologis. Kelelahan fisiologis adalah kelelahan yang timbul karena adanya perubahan faal tubuh, sedangkan kelelahan psikologis adalah kelelahan yang timbul akibat beban kerja mental seperti stres, gangguan psikis, atau adanya 
tekanan yang mengakibatkan psikologis terganggu.

PT. Yogya Indo Global yang berlokasi di Jalan Pleret KM 2.3 Potorono, Bantul, Yogyakarta merupakan perusahaan pengolahan kayu. Perusahaan ini mempunyai empat stasiun kerja yaitu stasiun kerja Plenner, Jointer, Telthing dan Potong Belah. Perusahaan ini memperkerjakan karyawan sebanyak 20 orang pekerja yang masing-masing setiap stasiun kerja terdiri dari 5 orang.

Perusahaan ini beraktivitas mulai pukul Pukul 07.00 sampai Pukul 16.00 dengan waktu istirahat selama 30 menit pada jam $12.00 \mathrm{WIB}$ 12.30 WIB. Dengan waktu istirahat selama 30 menit ini menyebabkan denyut nadi pekerja berkisar antara 107,7 sampai 125,5 denyut permenit. Berdasarkan denyut nadi normal lakilaki dewasa adalah 60-80 denyut per menit. Efek dari besarnya denyut nadi ini berpengaruh pada jumlah Konsumsi Energi yang besar dan masuk kedalam kategori beban kerja sedang (30\%$60 \%$ ) yang menyebabkan terjadinya kelelahan sehingga perlu adanya perbaikan.

Penelitian dilakukan dengan menentukan lamanya waktu istirahat berdasarkan beban kerja fisiologis sehingga diperoleh penentuan waktu istirahat untuk area kerja pemotongan kayu, dengan hasil penelitian ini diharapkan dapat mengevaluasi waktu istirahat guna meningkatkan produktivitas.

\section{METODE}

Setiap beban kerja yang diterima oleh seseorang harus sesuai atau seimbang baik dalam kemampuan fisik, kognitif, maupun keterbatasan manusia yang menerima beban kerja tersebut, ini dari sudut pandang ergonomi (Tarwaka, dkk, 2004). Kemampuan kerja seseorang tenaga kerja berbeda dari satu dengan yang lainnya dan sangat tergantung dari tingkat ketrampilan, kesegaran jasmani, usia dan ukuran tubuh dari pekerja yang bersangkutan. Beban kerja disebabkan oleh 2 hal yaitu beban kerja fisik (fisiologis) dan beban kerja mental (psikologis). Kerja mental merupakan kerja yang melibatkan proses berpikir dari otak kita. Pekerjaan ini akan mengakibatkan kelelahan mental bila kerja tersebut dalam kondisi yang lama, bukan diakibatkan oleh aktivitas fisik secara langsung. Sedangkan kerja fisik adalah kerja yang memerlukan energi otot fisik otot manusia sebagai sumber tenaga (power). Dalam kerja fisik konsumsi energi merupakan faktor utama yang dijadikan tolak ukur penentu berat atau ringannya suatu pekerjaan (Wignjosoebroto, 2003). Kerja fisik akan mengeluarkan energi yang berhubungan erat dengan konsumsi energi. Konsumsi energi pada waktu kerja biasanya ditentukan dengan cara tidak langsung, yaitu dengan pengukuran kecepatan denyut jantung dan konsumsi energi.

\subsection{Penilaian Beban Kerja Fisiologis}

Metode Penilaian Tidak Langsung

(1). Hitung denyut nadi dengan metode 10 denyut.

Denyut $/$ Menit $=\frac{10 \text { Denyut }}{\text { Waktu Penghitungan }} \times 60 .$.

(2). Klasifikasi beban kerja

$$
\% \mathrm{CVL}=\frac{100 \times(D N K-D N I)}{D N \max -D N I}
$$

(3). Konsumsi Energi

$$
\begin{aligned}
\mathrm{E}= & 1,80411-0,0229038 \mathrm{X}+4,71733 \\
& \mathrm{x} 10^{-4} \mathrm{X}^{2}
\end{aligned}
$$

2.2 Penentuan Waktu Istirahat Berdasarkan Beban Kerja Fisiologis

Hasil perhitungan konsumsi energi dapat dijadikan acuan untuk menghitung kebutuhan waktu istirahat dari kerja fisik yang dikonversikan ke dalam kebutuhan waktu istirahat dengan menggunakan persamaan Murrell:

$$
R=T \frac{(\mathrm{W}-\mathrm{S})}{\mathrm{W}-0.3}
$$

\section{HASIL DAN PEMBAHASAN}

Penelitian dilakukan di PT. Yogya Indo Global yang berlokasi di Jalan Pleret KM 2,3 Potorono, Bantul, Yogyakarta. Obyek yang diteliti adalah bagian area mesin pemotongan kayu yang terdiri dari 4 stasiun kerja yaitu Plenner, Jointer, Telthing dan Potong Belah.

Data yang diperlukan adalah :

(1) Data nama-nama mesin di Area Pemotongan Kayu, (2) Data nama dan usia pekerja, (3) Data waktu kerja dan waktu istirahat yang diterapkan perusahaan saat ini, (4) Data Denyut Nadi Kerja dan Denyut Nadi Istirahat

3.1 Menghitung Denyut Nadi dengan menggunakan Metode 10 Denyut.

Data waktu 10 denyut nadi pekerja di area pemotongan kayu yang dapat dilihat pada Tabel 1. Hasil perhitungan metode 10 denyut ada pada Tabel 2. 
Tabel 1. Data waktu 10 denyut nadi pekerja di area pemotongan kayu

\begin{tabular}{cllcccc}
\hline \multirow{2}{*}{ No } & \multirow{2}{*}{ Nama } & \multirow{2}{*}{ Stasiun Kerja } & \multirow{2}{*}{ DNI (detik) } & \multicolumn{2}{c}{ Denyut Nadi Kerja (detik) } & Rata-rata DNK \\
& & & 7,8 & 5,2 & 4,8 & 5,0 \\
(detik)
\end{tabular}

Tabel 2. Hasil perhitungan metode 10 denyut

\begin{tabular}{|c|c|c|c|c|c|c|}
\hline \multirow{2}{*}{ Stasiun Kerja } & \multirow{2}{*}{ No } & \multirow{2}{*}{ Nama } & \multirow{2}{*}{$\begin{array}{c}\text { DNI } \\
\text { (/menit) }\end{array}$} & \multicolumn{2}{|c|}{ DNK (/menit) } & \multirow{2}{*}{$\begin{array}{c}\text { Rata-rata DNK } \\
(/ \text { menit })\end{array}$} \\
\hline & & & & Pukul 09.30 & Pukul 15.00 & \\
\hline \multirow{6}{*}{ Plenner } & 1 & Parianto & 76,92 & 115,4 & 125,0 & 120,2 \\
\hline & 2 & Anang & 82,19 & 113,2 & 117,6 & 115,4 \\
\hline & 3 & Pagelan & 75 & 117,6 & 133,3 & 125,5 \\
\hline & 4 & Sagirin & 75,94 & 111,1 & 120,0 & 115,6 \\
\hline & 5 & Mujari & 84,5 & 113,2 & 117,6 & 115,4 \\
\hline & \multicolumn{2}{|c|}{ Rata-Rata } & & 114,1 & 122,7 & 118,4 \\
\hline \multirow{6}{*}{ Jointer } & 1 & Sapitri & 83,33 & 107,1 & 113,2 & 110,2 \\
\hline & 2 & Asrori & 86,95 & 117,6 & 122,4 & 120,0 \\
\hline & 3 & Priono & 85,71 & 113,2 & 120,0 & 116,6 \\
\hline & 4 & Isnawanto & 82,19 & 115,4 & 133,3 & 124,4 \\
\hline & 5 & Kirmadi & 80 & 107,1 & 117,6 & 112,4 \\
\hline & \multicolumn{2}{|c|}{ Rata-Rata } & & 112,1 & 121,3 & 116,7 \\
\hline \multirow{6}{*}{ Telthing } & 1 & Ari.w & 85,71 & 117,6 & 125,0 & 121,3 \\
\hline & 2 & Sarjono & 84,5 & 117,6 & 127,7 & 122,7 \\
\hline & 3 & Gunanto & 83,33 & 111,1 & 125,0 & 118,1 \\
\hline & 4 & Anta Roni & 88,23 & 117,6 & 133,3 & 125,5 \\
\hline & 5 & Agus & 85,71 & 113,2 & 120,0 & 116,6 \\
\hline & \multicolumn{2}{|c|}{ Rata-Rata } & & 115,5 & 126,2 & 120,8 \\
\hline \multirow{6}{*}{ Potong/Belah } & 1 & Karindi & 73,17 & 103,4 & 111,1 & 107,3 \\
\hline & 2 & Tukiram & 75,00 & 101,7 & 117,6 & 109,7 \\
\hline & 3 & Paimin & 71,43 & 98,4 & 117,6 & 108,0 \\
\hline & 4 & Ganjar & 68,97 & 98,4 & 117,6 & 108,0 \\
\hline & 5 & Sulamto & 73,17 & 100,0 & 115,4 & 107,7 \\
\hline & \multicolumn{2}{|c|}{ Rata-Rata } & & 100,4 & 115,9 & 108,1 \\
\hline
\end{tabular}

3.2 Menentukan \%CVL

\% CVL untuk klasifikasi beban kerja berdasarkan peningkatan denyut nadi kerja yang dibandingkan dengan Denyut Nadi Maksimum.
Klasifikasi beban kerja berdasarkan \%CVL dapat dilihat pada Tabel 3 . 
Tabel 3. Klasifikasi beban kerja berdasarkan \%CVL

\begin{tabular}{clccc}
\hline No & Stasiun Kerja & $\%$ CVL & Kategori Beban Kerja & Klasifikasi \%CVL \\
\hline 1 & Plenner & $36,7 \%$ & Sedang & Diperlukan Perbaikan \\
2 & Jointer & $31,8 \%$ & Sedang & Diperlukan Perbaikan \\
3 & Telthing & $34,9 \%$ & Sedang & Diperlukan Perbaikan \\
4 & Potong/belah & $28,1 \%$ & Ringan & Tidak Terjadi Kelelahan \\
\hline
\end{tabular}

Tabel 4. Hasil perhitungan konsumsi energi di area pemotongan kayu

\begin{tabular}{clcc}
\hline \multirow{2}{*}{ No } & \multicolumn{2}{c}{ Stasiun Kerja } & \multicolumn{2}{c}{ Konsumsi Energi Hasil Pengukuran (Kkal/menit) } \\
& & Pukul 07.00 - 09.30 & Pukul 12.30 - 15.00 \\
\hline 1 & Plenner & 5,32 & 6,11 \\
2 & Jointer & 5,13 & 5,95 \\
3 & Telthing & 5,42 & 6,41 \\
4 & Potong/Belah & 4,27 & 5,47 \\
\hline
\end{tabular}

Tabel 5. Hasil perhitungan kebutuhan waktu istirahat

\begin{tabular}{clcccc}
\hline \multirow{2}{*}{ No } & \multirow{2}{*}{ Stasiun Kerja } & \multicolumn{2}{c}{$\begin{array}{c}\text { Konsumsi Energi Shift Kerja } \\
(\text { Kkal/menit) }\end{array}$} & \multicolumn{2}{c}{ Kebutuhan Istirahat (menit) } \\
\cline { 3 - 6 } & & Pukul 09.30 & Pukul 15.00 & Pukul 09.30 & Pukul 15.00 \\
\hline 1 & Plenner & 5,32 & 6,11 & 10 menit & 28 menit \\
2 & Jointer & 5,13 & 5,95 & 5 menit & 25 menit \\
3 & Telthing & 5,42 & 6,41 & 13 menit & 35 menit \\
4 & Potong/Belah & 4,27 & 5,47 & 0 & 14 menit \\
\hline
\end{tabular}

3.2 Menghitung jumlah konsumsi energi berdasarkan Denyut Nadi Kerja menggunakan persamaan Regresi Kuadratis

Dari Tabel 3 diketahui ada tiga Stasiun Kerja yang berada pada beban kerja sedang yaitu Mesin Plenner, Jointer, Telthing dan Potong Belah dengan \%CVL berada antara 30\%-60\% dan perlu adanya perbaikan pada waktu istirahatnya, untuk menghitung Konsumsi Energi, dibuat persamaan hubungan antara Denyut Nadi dengan Konsumsi Energi menggunakan persamaan Regresi Kuadratis, hasil perhitungan disajikan pada Tabel 4.

\subsection{Menghitung waktu istirahat}

Pengaturan waktu istirahat berdasarkan beban kerja fisiologis

Kebutuhan waktu istirahat pada mesin Plenner:

a. Pada Pukul 09.30 WIB:

$$
\begin{aligned}
& R=150 \text { menit } \frac{(5,32-5)}{5,32-0.3} \\
& R=\frac{336 \mathrm{Kkal} / \text { menit }}{5,4 \mathrm{Kkal}} \\
& R=9,56 \text { menit } \sim 10 \text { menit }
\end{aligned}
$$

b. Pada pukul 15.00 WIB:

$$
\begin{aligned}
& R=150 \text { menit } \frac{(6,11-5)}{6,11-0,3} \\
& R=\frac{166,5 \mathrm{Kkal} / \text { menit }}{5,81 \mathrm{Kkal}} \\
& R=28,65 \text { menit } \sim 29 \text { menit }
\end{aligned}
$$

Hasil perhitungan waktu istirahat untuk 4 stasiun kerja ada disajikan pada Tabel 5.

3.5 Perbandingan konsumsi energi sebelum dan setelah penelitian

Jika konsumsi energi diukur berdasarkan waktu istirahat yang ditentukan oleh perusahaan yaitu mulai pukul 07.00 WIB hingga pukul 12.00 WIB dengan total bekerja 5 jam terus menerus, maka jumlah konsumsi energi yang dikeluarkan selama bekerja dapat dibandingkan dengan konsumsi energi dari hasil pengukuran. Untuk menghitung konsumsi energi dapat dilakukan dengan menggunakan Regresi Kuadratis yang didapat dari kecepatan Denyut Nadi Kerja. Hasil pengukuran Denyut Nadi Kerja berdasarkan waktu istirahat yang ditentukan oleh perusahaan dapat dilihat pada Tabel 6.

Dari hasil pengukuran Denyut Nadi Kerja berdasarkan waktu istirahat yang ditentukan perusahaan, selanjutnya dapat dihitung jumlah konsumsi energi saat kerja yang dikeluarkan oleh pekerja di Area Pemotongan Kayu. Perhitungan dilakukan dengan menggunakan Regresi Kuadratis (Konz, 1998). Berikut contoh perhitungan Konsumsi Energi berdasarkan waktu istirahat yang ditentukan oleh perusahaan 
Konsumsi energi mulai pukul 07.00-12.00 (Mesin Planner)

$\mathrm{E}=1.80411-0.0229038 \mathrm{X}+4.71733 \times 10^{-4} \mathrm{X}^{2}$

$\mathrm{E}=1.80411-0.0229038(129.3)+4.71733 \times 10^{-4}$ $(129.3)^{2}$

$\mathrm{E}=1.80411-2.96+7.89$

$\mathrm{E}=6.73 \mathrm{Kkal} / \mathrm{menit}$

Konsumsi Energi berdasarkan fakta di lapangan ini dapat dibandingkan dengan hasil pengukuran yang telah dilakukan untuk dilakukan perbaikan waktu istirahat. Hasil peningkatan jumlah konsumsi energi berdasarkan penelitian untuk menentukan perbaikan waktu istirahat dapat dilihat pada Tabel 8.
Setelah dilakukan hasil perhitungan Konsumsi Energi berdasarkan waktu istirahat yang diterapkan oleh perusahaan, selanjutnya dapat dibandingkan dengan hasil pengukuran berdasarkan beban kerja fisiologis yang dialami oleh para pekerja. Perbandingan hasil perhitungan konsumsi energi sebelum dan setelah pengukuran dapat dilihat pada Tabel 7 dan Tabel 8.

Dari Tabel 7 telihat bahwa sejak pekerja memulai pekerjaan pada pukul 07.00 WIB terjadi peningkatan konsumsi energi secara terus menerus hingga pukul 12.00 WIB dimana pada jam ini pekerja beristirahat selama 30 menit. Akan tetapi, waktu untuk beristirahat ini belum sepenuhnya memulihkan energi yang terjadi selama 5 jam bekerja.

Tabel 6. Hasil pengukuran denyut nadi kerja berdasarkan waktu kerja perusahaan

\begin{tabular}{|c|c|c|c|c|}
\hline \multirow{2}{*}{ Stasiun Kerja } & \multirow{2}{*}{ No } & \multirow{2}{*}{ Nama } & \multicolumn{2}{|c|}{ DNK Berdasarkan Jam Perusahaan (denyut/menit) } \\
\hline & & & Pukul $07.00-12.00$ & Pukul $12.30-16.00$ \\
\hline \multirow{6}{*}{ Plenner } & 1 & Parianto & 139,5 & 146,3 \\
\hline & 2 & Anang & 122,4 & 127,7 \\
\hline & 3 & Pagelan & 139,5 & 125,0 \\
\hline & 4 & Sagirin & 125,0 & 125,0 \\
\hline & 5 & Mujari & 120,0 & 127,7 \\
\hline & \multicolumn{2}{|c|}{ Rata-Rata } & 129,3 & 130,3 \\
\hline \multirow{6}{*}{ Jointer } & 1 & Sapitri & 117,6 & 120,0 \\
\hline & 2 & Asrori & 125,0 & 130,4 \\
\hline & 3 & Priono & 120,0 & 125,0 \\
\hline & 4 & Isnawanto & 133,3 & 139,5 \\
\hline & 5 & Kirmadi & 117,6 & 120,0 \\
\hline & \multicolumn{2}{|c|}{ Rata-Rata } & 122,7 & 127,0 \\
\hline \multirow{6}{*}{ Telthing } & 1 & Ari.w & 125,0 & 130,4 \\
\hline & 2 & Sarjono & 127,7 & 127,7 \\
\hline & 3 & Gunanto & 125,0 & 127,7 \\
\hline & 4 & Anta Roni & 133,3 & 136,4 \\
\hline & 5 & Agus & 120,0 & 125,0 \\
\hline & \multicolumn{2}{|c|}{ Rata-Rata } & 126,2 & 129,4 \\
\hline \multirow{6}{*}{ Potong/Belah } & 1 & Karindi & 111,1 & 113,2 \\
\hline & 2 & Tukiram & 120,0 & 120,0 \\
\hline & 3 & Paimin & 117,6 & 122,4 \\
\hline & 4 & Ganjar & 122,4 & 125,0 \\
\hline & 5 & Sulamto & 120,0 & 122,4 \\
\hline & \multicolumn{2}{|c|}{ Rata-Rata } & 118,2 & 120,6 \\
\hline
\end{tabular}

Setelah istirahat selama 30 menit, pekerja melanjutkan pekerjaannya kembali hingga jam kerja selesai. Kurangnya waktu istirahat ini dapat kembali meningkatkan konsumsi energi hingga jam kerja perusahaan selesai pada pukul 16.00 WIB. Setelah dilakukan hasil perhitungan Konsumsi Energi berdasarkan waktu istirahat yang diterapkan oleh perusahaan, selanjutnya dapat dibandingkan dengan hasil pengukuran berdasarkan beban kerja fisiologis yang dialami oleh para pekerja. Perbandingan hasil perhitungan konsumsi energi sebelum dan setelah pengukuran dapat dilihat pada Tabel 7 dan Tabel 8. 
Tabel 7. Konsumsi energi tiap jam berdasarkan waktu kerja perusahaan

\begin{tabular}{lcccccccccc}
\hline & \multicolumn{8}{c}{ Konsumsi Energi Berdasarkan Waktu Istirahat Perusahaan (Kkal/menit) } \\
\cline { 2 - 11 } Stasiun Kerja & Jam & Jam & Jam & Jam & Jam & Jam & Istirahat & Jam & Jam & Jam \\
& 07.00 & 08.00 & 09.00 & 10.00 & 11.00 & 12.00 & & 14.00 & 15.00 & 16.00 \\
\hline Plenner & 5 & 5,24 & 5,3 & 5,94 & 6,37 & 6,73 & 6,51 & 6,58 & 6,67 & 6,83 \\
Jointer & 5 & 5,11 & 5,13 & 5,62 & 5,86 & 6,1 & 5,86 & 6,32 & 6,46 & 6,50 \\
Telthing & 5 & 5,26 & 5,37 & 5,91 & 6,34 & 6,43 & 6,28 & 6,33 & 6,68 & 6,74 \\
Potong/Belah & 5 & 5,14 & 5,23 & 5,36 & 5,57 & 5,69 & 5,55 & 5,72 & 5,83 & 5,90 \\
\hline Rata-rata & & 5,188 & 5,26 & 5,71 & 6,04 & 6,24 & 6,05 & 6,24 & 6,41 & 6,50 \\
\hline
\end{tabular}

Dari Tabel 7 telihat bahwa sejak pekerja memulai pekerjaan pada pukul 07.00 WIB terjadi peningkatan konsumsi energi secara terus menerus hingga pukul 12.00 WIB dimana pada jam ini pekerja beristirahat selama 30 menit. Akan tetapi, waktu untuk beristirahat ini belum sepenuhnya memulihkan energi yang terjadi selama 5 jam bekerja. Setelah istirahat selama 30 menit, pekerja melanjutkan pekerjaannya kembali hingga jam kerja selesai. Kurangnya waktu istirahat ini dapat kembali meningkatkan konsumsi energi hingga jam kerja perusahaan selesai pada pukul 16.00 WIB.

Tabel 8. Konsumsi energi tiap jam setelah dilakukan perbaikan

\begin{tabular}{lccccccccccc}
\hline & \multicolumn{10}{c}{ Konsumsi Energi Berdasarkan Penelitian (Kkal/menit) } \\
\cline { 2 - 12 } Stasiun Kerja & Jam & Jam & Jam & Istirahat & Jam & Jam & stirahat & Jam & Jam & Istirahat & Jam \\
& 07.00 & 08.00 & 09.30 & & 11.00 & 12.00 & & 14.00 & 15.00 & & 16.00 \\
\hline Plenner & 5 & 5,24 & 5,32 & 5,28 & 5,48 & 5,74 & 5,58 & 6,34 & 6,56 & 6,36 & 6,67 \\
Jointer & 5 & 5,11 & 5,13 & 5,11 & 5,46 & 5,68 & 5,54 & 5,87 & 5,95 & 5,76 & 5,82 \\
Telthing & 5 & 5,26 & 5,42 & 5,31 & 5,67 & 5,86 & 5,65 & 5,73 & 5,86 & 5,64 & 5,78 \\
Potong Belah & 5 & 5,14 & 5,27 & 5,16 & 5,32 & 5,48 & 5,35 & 5,46 & 5,62 & 5,37 & 5,62 \\
\hline Rata-rata & & 5,19 & 5,29 & 5,22 & 5,48 & 5,69 & 5,53 & 5,85 & 6,00 & 5,78 & 5,97 \\
\hline
\end{tabular}

Dari Tabel 8 terlihat bahwa jika waktu istirahat ditambah di antara waktu kerja perusahaan pada shift pertama (Jam 09.30 WIB) dan kedua (Jam 15.00 WIB) maka jumlah konsumsi energi tidak mengalami peningkatan yang sangat tinggi. Penyisipan waktu istirahat dengan cara ini telah banyak diterapkan oleh perusahaan-perusahaan yang memiliki pekerja dengan tipe kerja yang mengandalkan kerja fisik sehingga dapat menjadi acuan oleh perusahaan untuk dapat menambah waktu istirahat bagi para pekerjanya.

Selanjutnya dari Tabel 7 dan Tabel 8 dapat dibuat grafik perbandingan peningkatan Konsumsi Energi berdasarkan Waktu Istirahat Perusahaan dan Waktu Istirahat Penelitian, seperti pada Gambar 1

Pada Gambar 2 terlihat bahwa adanya peningkatan konsumsi energi sejak mulai bekerja hingga jam istirahat siang Jam 12.00 WIB. Peningkatan ini terus bertambah seiring dengan bertambah juga jam kerja selesai pada pukul 16.00 WIB. Dengan adanya penyisipan waktu istirahat pada Jam 09.30 WIB maka kelelahan dapat sedikit diminimalisir sehingga peningkatan konsumsi energi sampai jam istirahat siang tidak terlalu tinggi. Begitu juga selanjutnya hingga jam kerja selesai. Meskipun tingkat konsumsi energi pada tiap stasiun kerja berbeda-beda, dengan adanya penambahan jam istirahat maka jumlah konsumsi energi yang dikeluarkan oleh pekerja menjadi sedikit berkurang dibandingkan dengan sebelum dilakukannya perbaikan. Hal ini tentunya berpengaruh juga terhadap kelelahan yang dirasakan oleh para pekerja. 


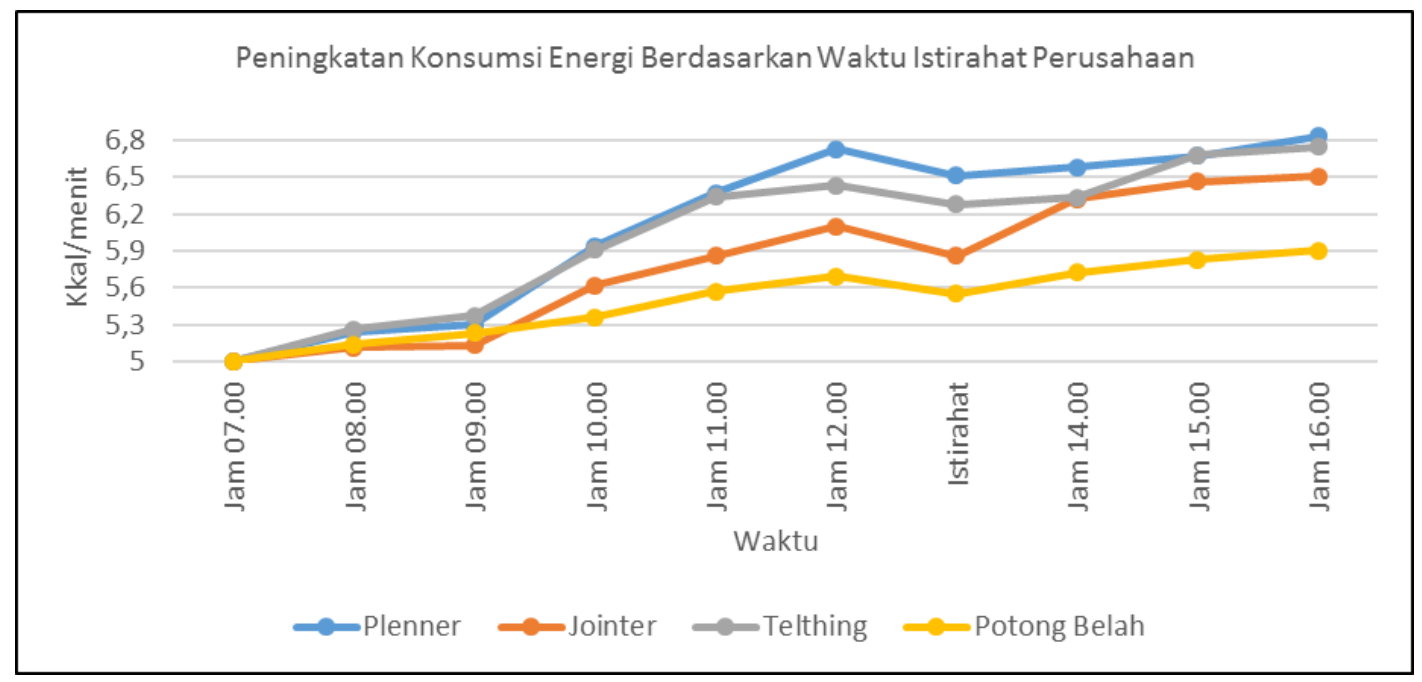

Gambar 1. Grafik peningkatan konsumsi energi sebelum perbaikan waktu istirahat

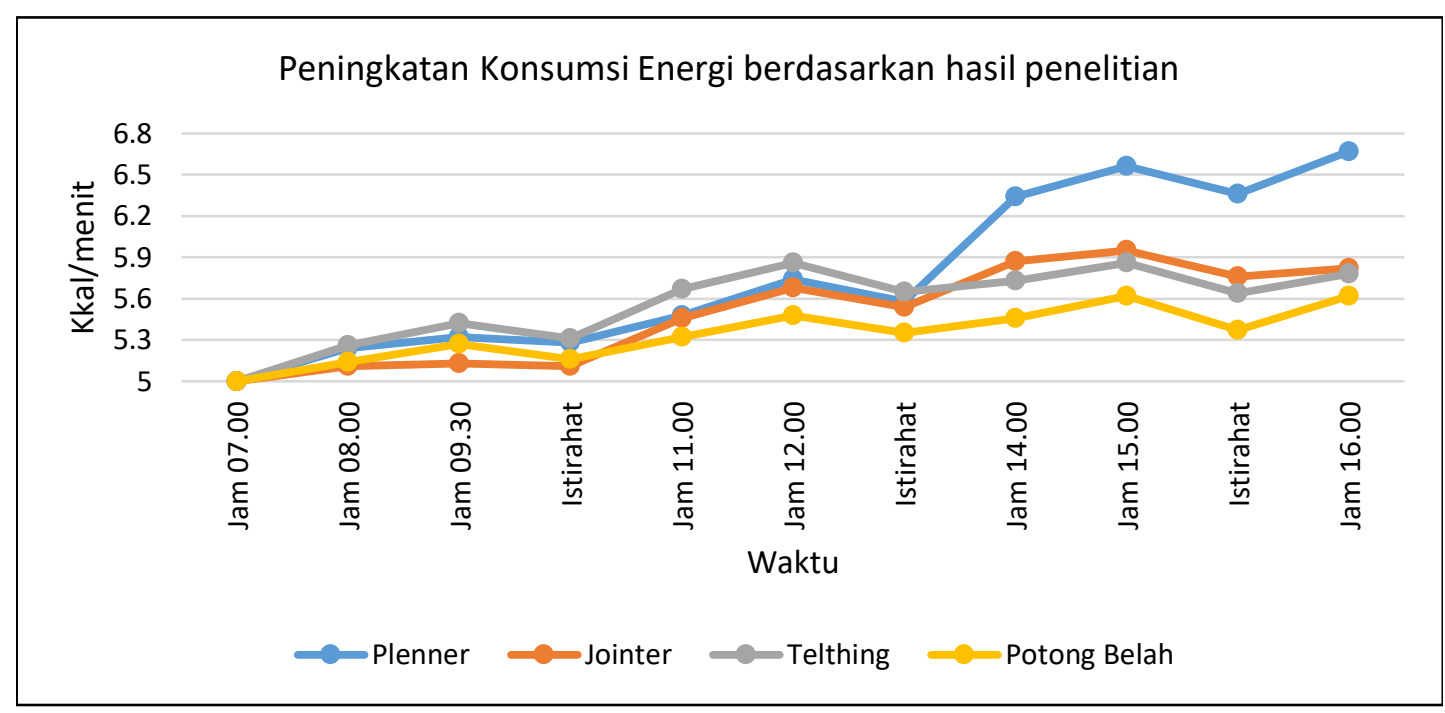

Gambar 2. Grafik peningkatan konsumsi energi setelah perbaikan waktu istirahat

\section{KESIMPULAN}

Kesimpulan yang dapat diambil adalah (1) Berdasarkan klasifikasi \%CVL untuk proses mesin Plenner, Jointer dan Telthing perlu dilakukan perbaikan/penambahan waktu istirahat karena berada pada 30\%-60\% dengan beban kerja sedang. Sedangkan untuk mesin Potong Belah masih dalam kategori beban kerja ringan sehingga tidak perlu penambahan istirahat. (2) Perbaikan waktu istirahat adalah dengan ditambahkan pada dua shift yaitu pada Pukul 09.30 dan Pukul 15.00 menjadi 60 menit sesuai dengan kebutuhan waktu istirahat berdasarkan konsumsi energi yang dikeluarkan pekerja di tiap Stasiun Kerja.

\section{DAFTAR PUSTAKA}

Christensen, E.H. (1991). Physiology of Work. Encyclopedia of Occupational Health and Safety. 3nd Edition. Geneva: ILO. p. 1698-1700.

Kilbon, A. (1992). Measurement and Assessment of Dynamic Work. Dalam: Evaluation of Human Work. A Practical Ergonomic Methodology, ed. by Wilson, JR dan Corlett, EN, Taylor and Francis, London: pp. 520-542. pp. 641-661.

Konz, S., (1998), Work/Rest: Part II - The Scientific Basis (Knowledge Base) for the Guide, International Journal of Industrial Ergonomics, Vol. 22, Hlm. 73-99. 
Manuaba, A. (2005). Ergonomi dalam Industri. Universitas Udayana.

Nurmianto, E. (1996). Ergonomi Konsep Dasar dan Aplikasinya. Guna Widya, Institut Teknologi sepuluh November, Surabaya.

Rodahl, K. (1989). The Physiologi of Work. London: Taylor \& Francis.

Sastrowinoto, S. (1985). Meningkatkan Produktifitas dengan Ergonomi, Jakarta: Pustaka Binaman Pressindo.
Sutalaksana, I.Z. (1979). Teknik Tata Cara Kerja. Bandung: ITB.

Tarwaka, Solichul H.B, Lilik S. (2004). Ergonomi untuk Keselamatan Kerja dan Produktivitas. Surakarta: Uniba Press.

Wignjosoebroto, S. (2003). Ergonomi Studi Gerak dan Waktu. Edisi Pertama. Jakarta: Guna Widya. 